\title{
The use of digital technologies in building organizational and technological design
}

\author{
Pavel Kagan*
}

Moscow State University of Civil Engineering, Yaroslavskoe shosse, 26, Moscow, 129337, Russia

\begin{abstract}
The article discusses the development of digital technologies in construction. The relevance of the introduction of digital technologies in construction is determined by a set of tasks set in the light of the development of the entire digital economy of the country. Such basic regulatory documents as: "The Strategy for the Development of the Information Society of the Russian Federation for 2017-2030", the Program "Digital Economy of the Russian Federation", Decree of the President of the Russian Federation No. 204 "On National Goals and Strategic Tasks of the Development of the Russian Federation for the Period until 2024" are considered. The problems of the innovative development of the construction industry require the integrated implementation of digital technologies in solving various problems in the production of building materials, construction design and, in fact, construction production. One of the main directions of digitalization of construction is the digitalization of design, since it is at this stage that the basic qualitative characteristics of future construction products are laid.In particular, the author examined the problems of automating the formation of organizational and technological documentation. The development trends of the digital economy in the construction industry are identified. The classification of the use of promising digital technologies in construction design and production is given. The existing system of designing organizational and technological documentation can no longer solve the problems listed above. The way out is seen in the creation of new digital technologies for the formation of organizational and technological documentation.
\end{abstract}

\section{Introduction}

Digitalization of construction is a difficult problem, which is a whole complex of digital technologies implementation in solving various problems of the construction industry. One of the main directions of digitalization of construction is the digitalization of design, since it is at this stage that the main qualitative characteristics of future construction products are laid.

\footnotetext{
* Corresponding author: kagan@mgsu.ru
} 
The existing automated systems for the development of design documentation for the organization and construction technology do not currently provide a further expansion of the capabilities of modern computing technology due to their limitations, inflexibility of "task technology", information isolation, etc.

After the architectural, construction and design stage, a technological process for the construction of the facility is designed taking into account the specific features of the site and the participants in the construction.

The design of the organization of construction production is a whole range of works, the result of which is the organizational and technological documentation containing the organizational and technical conditions for the activities of production units, ensuring the rational use of resources and the release of construction products. As shown in [1], "the organization of construction production should ensure the mutual consistency of all organizational, technical and technological solutions to achieve the final result - putting the facility into operation with the required quality and on time."

\section{Methods}

The existing level of digital technologies in the field of design and organization of construction production does not allow talking about solving the problems of design automation. "The software does not meet the needs of the engineering services of design and contracting organizations due to their locality, inflexibility of the" task technology ", software and information dissociation" [2].

"There is also a vacuum in the field of scientific foundations for solving the problems facing the once powerful system of organizational and technological construction design" [2].

By the decree of the President of the Russian Federation of 09.05.2017 No. 203 "On the Strategy for the Development of the Information Society in the Russian Federation for 2017-2030", it is planned to create the so-called ecosystem of the digital economy of the Russian Federation. The introduction of digital technologies, as shown by foreign and Russian practice and theoretical studies, is implemented on the basis of digital platforms that integrate technological processes and form digital service systems served by a new category of business structures in the relevant field - service integrators, their importance in the economic development of the construction industry is significant. degree is increasing, however, the mechanisms and methods of managing such structures and their assessment, as well as network interconnection with other economic actors and other issues have not yet been sufficiently investigated and developed. The mechanism for implementing such a relationship remains insufficiently studied and determines the need for the development of tools for its identification, methods of assessment and management.

According to the estimates of the World Economic Forum, Global Construction 2030 and other events and organizations, digitalization of the economy has enormous economic potential for business and society over the next decade. As at the stage of design and construction of facilities, especially large ones, full-scale digitalization will lead to huge cost savings - up to 1.2 trillion. dollars, and at the stage of their operation - up to 0.5 trillion. dollars worldwide. The Russian Federation recognizes the need to accelerate the digitalization processes in the economy in order to achieve competitive positions and integration in the digital space of the world economy. Today digital technologies are not only a priority for innovative firms, but are a necessity for all enterprises, have become a mass phenomenon, including in the construction industry, without a global network, no successful enterprise can exist. The penetration of digitalization into all spheres of the country's economy is associated with an increase in the level of service potential of socioeconomic systems. 
The digital economy is impossible without the digitalization of society, business and government at the same time. Back in 2011, the "Strategy for the Innovative Development of the Russian Federation for the Period until 2020" was adopted (Order of the Government of the Russian Federation dated December 8, 2011 No. 2227-r), which states that "... in the range of sectors with the potential for rapid adaptation of advanced technologies, includes ... construction ... ".

Realization of the "potential of the digital economy by directly embedding digital technologies in the economic mechanism of enterprises" will guarantee the competitive advantages of the Russian Federation at the international level [3]. The political decision in this area was made in the Program "Digital Economy of the Russian Federation" (approved of July 28, 2017 No. 1632-r).

Within the framework of the state program of the Russian Federation "Information Society (2011-2020)" (Strategy for the Development of the Information Society in the Russian Federation for 2017-2030), measures are planned to develop information and telecommunication infrastructure, introduce information technologies into the public administration system and workflow.

The Decree of the President of the Russian Federation of May 7, 2018 outlines a range of tasks to be solved by 2024, among which, when developing a national project in the field of housing and the urban environment, it is necessary to modernize the construction industry, "... including through the establishment of restrictions on the use of outdated technologies and incentives introduction of advanced technologies in design and construction ... "; when implementing the national program "Digital Economy of the Russian Federation", it should be ensured "... the creation of a stable and secure information and telecommunications infrastructure for high-speed transmission, processing and storage of large amounts of data, available to all organizations and households; the use of mainly domestic software by state bodies, local governments and organizations ... "and the following tasks were solved:" ... the introduction of civil circulation based on digital technologies ... "; "... the creation of end-to-end digital technologies mainly based on domestic developments" ...; "... transformation of priority sectors of the economy and social sphere, including ... construction, urban economy, ... financial services, through the introduction of digital technologies and platform solutions ...".

It should be noted that manufacturing enterprises are among the most inert areas that use digital technologies in comparison, for example, with the financial sector, energy, etc. The trend towards digitalization of the economy that has emerged in the world stimulates the production sector, including construction, to actively introduce digital technologies ...

There are known works on the development of the digital economy in Russia, for example, the work of scientists [4-15]. The accumulated research experience shows that in the digital economy, the development of an innovative digital environment is a necessity to gain competitive advantages and develop the ecosystem of the digital economy of the Russian Federation.

According to the Strategy for the Development of the Information Society in the Russian Federation for 2017-2030, "multidimensional project management systems integrated with systems for modeling and managing the life cycle of objects of a new level will ensure the required quality of object and process analysis and management decisions, including deployed cost management systems, construction time, investment and project risks. The introduction of project management based on modern information models should contribute to realizing the potential for innovative development of the construction industry. "

The draft Strategy for the innovative development of the construction industry of the Russian Federation until 2030 identifies trends in the innovative development of 
architectural and construction design and the tasks of implementing state policy (clause 5.1.2 of the Strategy).

Among the problems affecting the quality of design work, the quality of the developed design documentation and the timing of its preparation, it was revealed, among others, the imperfection of the legal and regulatory framework for the design, the imperfection of the methodology and design technology, including in typical design;

- lack of high-quality domestic software for design work, the use of outdated software packages for design work and calculation of estimates;

- lack of uniform standards defining the basic standards and design rules using the technology of information modeling of an object (BIM design);

- imperfection of mechanisms ensuring the timely inclusion of innovations in the documents of technical regulation of the construction industry.

\section{Results}

The lack of regulatory frameworks for the implementation and use of information modeling technologies in design (BIM-design) and, as a result, the impossibility of introducing modern technologies to implement all stages of the project life cycle, makes it impossible to save budget funds at the stage of construction and installation, operation, reconstruction and liquidation of the facility.

Today, automated computer systems are used at all stages of the creation of construction products, for example: Microsoft Project, Primavera, Spider Project, "Hector: designerbuilder", "PLAN 2000 Project Management", "1C: Construction Contractor 3.0. Management of construction production "," MyPrimavera "," ISUP based on Primavera 5.0 "," Altius - Construction management "and many others.

Among the main areas of digitalization abroad, along with robotization, cloud technologies, computers and mobile devices at construction sites, BIG DATA information storage centers, information modeling technologies, which differ significantly from other types of design work, occupy an important place.

If you add additional parameters to the model - time and cost, which allow you to calculate the parameters of construction processes even before starting work at the facility and plan production processes, then this will already be the so-called 5D model, which is designed to optimize the construction process. Or, if you replace any material or product, this replacement will automatically be reflected in the corresponding technical and operational documentation on the drawings, in the appearance of the object and the consumption of resources. It is assumed that solutions based on BIM technology allow you to perform 4D visualization of the construction process, identify possible conflicts in the documentation, determine the estimated cost by option, allow you to exchange with customers and regulatory authorities, optimize processes, reduce material costs, accelerate construction time and save money ...

Software solutions that implement BIM modeling in construction can have cloud storage, remote access and include the following most popular: AUTODESK REVIT, Revit Server, ARCHICAD, Tekla Structures, Tekla BIMsigh, MagiCAD, AutoCAD Civil 3D, GRAPHISOFT, Renga Architecture.

Among domestic similar developments, one can cite an example of a project management system for the construction of complex engineering facilities, capital construction facilities Multi-D, developed by the United Company JSC NIAEP - JSC Atomstroyexport. This design technology allows you to effectively manage the budget, terms and quality - the main parameters of design and construction.

The main directions of development of digital technologies in construction are shown in Fig. one. 


\section{Discussion}

Since 2019, the Urban Planning Code of the Russian Federation has been supplemented with the concept of "information modeling", and, according to the Deputy Minister of Construction of the Russian Federation D. Volkov, the introduction of BIM "... will help in the fight against administrative barriers, improve the interaction of various parties in construction, and also strengthen cooperation in matters of interstate cooperation".

More and more construction corporations are switching to BIM models: TsNIIpromzdaniy, for example, has begun to develop a construction information classifier for maintaining and generating BIM models, Polis Group is also switching to information modeling, there are other examples.

\section{Conclusions}

The scientific and technical hypothesis of the study consists in the assumption of the possibility of increasing the efficiency of organizational and technological design in construction due to its modernization using modern digital technologies.

At the same time, a methodology for the automation of organizational and technological design in construction should be formulated, which ensures the organization of functional subsystems and the solution of the most important problems.

The existing design system with organizational and technological documentation can no longer solve the problems listed above. The way out is seen in the creation of new, digital technologies for the formation of organizational and technological documentation.

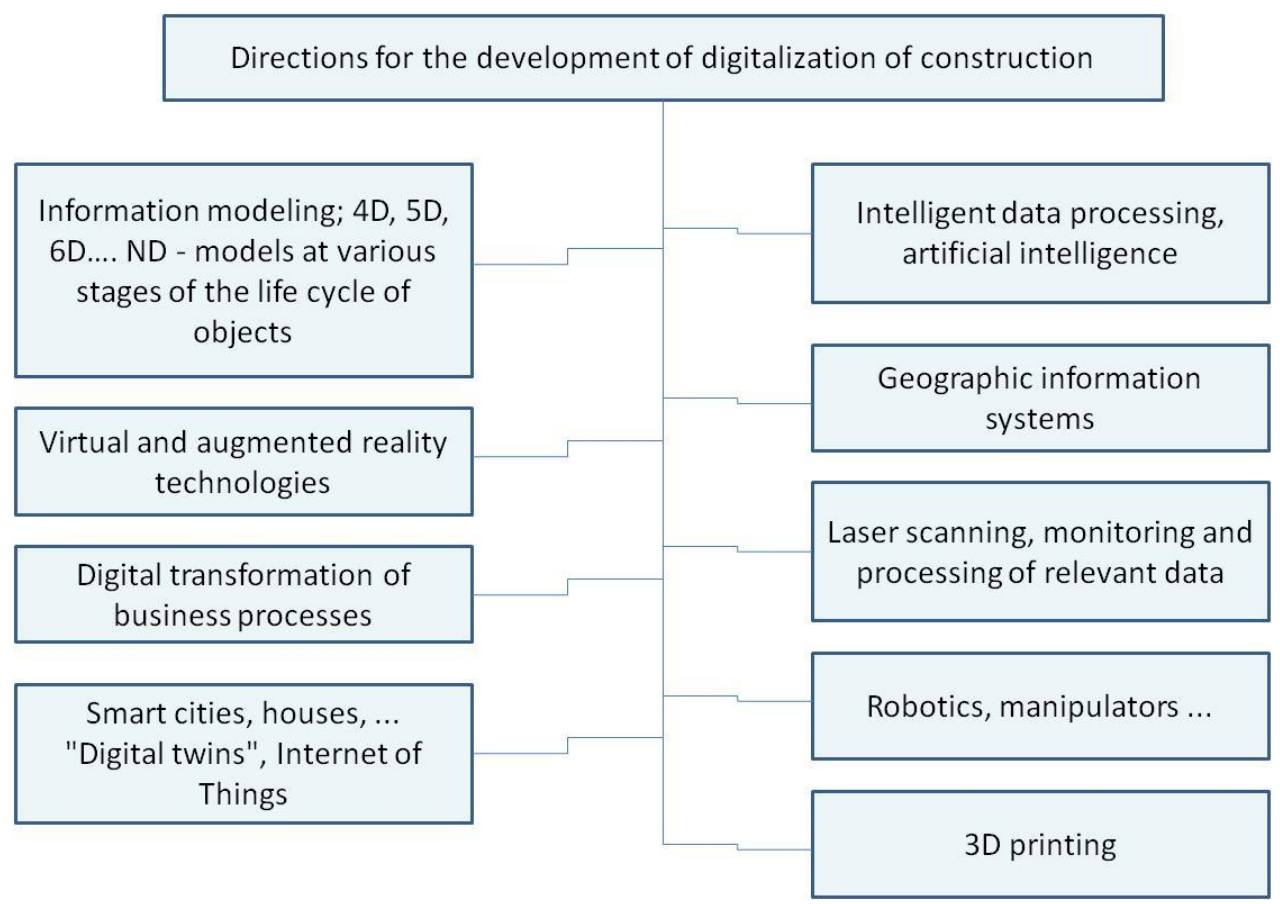

Fig. 1. Directions for the development of digital technologies in construction. 


\section{References}

1. Ginzburg A.V., Tsybulskaya O. 2008 Automation systems for organizational and technological design Vestnik MGSU vol 1 pp 352-357

2. Kagan P.B., Kulikova E.N., Malykha G.G., Kulakova V.V., Sheina S.G. 2018 Functional-system analysis and systems engineering of organizational and technological design in construction Nauka i biznes: puti razvitiya vol 9 (87) pp 11-16

3. Tolstykh T.O., Shkarupeta E.V., Gamidullaeva L.A. 2018 DIGITAL INNOVATIVE PRODUCTION ON THE BASIS OF FORMATION OF THE ECOSYSTEM OF SERVICES AND RESOURCES EKONOMIKA V PROMYSHLENNOSTI vol $112 \mathrm{pp}$ $159-168$

4. Asaul V.V., Lushnikov A.S. 2019 IMPLEMENTATION OF ELEMENTS OF DIGITAL ECONOMY IN CONSTRUCTION: DOMESTIC AND FOREIGN EXPERIENCE / Collection "Economic problems in architecture, urban planning and investment and construction activities. Current state and challenges "- materials of the All-Russian scientific-practical conference of the members of the RAASN, the teaching staff, young scientists of SPbGASU and specialists in the investment and construction sector. St. Petersburg, pp 89-93.

5. Vishnivetskaya A.I., Ablyazov T.Kh. 2019 Digital strategy as the basis for digital transformation of construction organizations Ekonomika: vchera, segodnya, zavtra vol 9 Issue $3 \mathrm{~A}$ pp 11-20

6. Vorobiev V.S., Sinitsyna A.S., Katalymova K.V., Zapashchikova N.P. 2018 SIMULATION MODELING IN THE STRUCTURE OF CREATION OF BIMTECHNOLOGIES OF CONSTRUCTION PROJECTS Izvestiya vysshikh uchebnykh zavedeniy. Stroitel'stvo. vol 5 (713) pp 105-115

7. Ginzburg A.V., Volkov A.A. and other 2014 Design automation systems in construction: a tutorial (Publishing house MISI-MGSU) p 664

8. Dmitriev A.N. 2018 DEVELOPMENT OF DIGITAL METHODS FOR EVALUATING INNOVATIONS IN INVESTMENT AND CONSTRUCTION PROJECTS TO INCREASE THEIR ENERGY EFFICIENCY Promyshlennoye $i$ grazhdanskoye stroitel'stvo vol $7 \mathrm{pp}$ 13-20

9. Dmitriev A.N., Bareshenkova K.A., Marchenkova S.V. 2019 THE CONCEPT OF TRANSITION TO THE IMPLEMENTATION OF DIGITAL INFORMATION MODELING TECHNOLOGIES IN MOSCOW CONSTRUCTION / Collection "Modern problems of project management in the investment and construction sphere and environmental management" - materials of the IX International scientific-practical conference dedicated to the 112th anniversary of the PRUE. G.V. Plekhanov, Moscow, pp 208-220

10. Dobrynin A.P., Chernykh K.Yu., Kupriyanovskiy V.P., Kupriyanovskiy P.V., Sinyagov S.A. 2016 Digital Economy - Various Ways to Effective Application of Technologies (BIM, PLM, CAD, IOT, Smart City, BIG DATA and others) International Journal of Open Information Technologies vol 4 Issue 1pp 4-11

11. Korabelnikova S.S., Korabelnikova S.K. 2019 DIGITAL TECHNOLOGIES AS AN ELEMENT OF RISK REDUCTION IN CONSTRUCTION Diskussiya vol 2 (93) pp $18-27$

12. Leskova Yu.G. 2018 APPLICATION OF INFORMATION (DIGITAL) TECHNOLOGIES IN SELF-REGULATION AS A CONDITION FOR 
DEVELOPMENT OF THE CONSTRUCTION INDUSTRY AND LEGAL REGULATION Grazhdanskoye pravo vol 5 pp 9-11

13. Semenov A.A. 2018 TRAINING OF SPECIALISTS IN THE FIELD OF BIM TECHNOLOGIES FOR THE DEVELOPMENT OF THE DIGITAL ECONOMY IN CONSTRUCTION. NEW INFORMATION TECHNOLOGIES IN ARCHITECTURE AND CONSTRUCTION / Materials of the All-Russian Scientific Conference with International Participation.. Publisher: Ural State University of Architecture and Art, Yekaterinburg, $\mathrm{p} 44$

14. Travush V.I. 2018 Digital technologies in construction Academia. Arkhitektura $i$ stroitel'stvo. vol 3 pp 107-117

15. Travush V.I. Belostyky A.M., Akimov P.A. 2018 DIGITAL TECHNOLOGIES IN CONSTRUCTION: DECLARATIONS AND REALITY. PART 2. EXPERIMENTAL AND LOCAL RESEARCH, PRODUCTION OF MATERIALS, PRODUCTS AND STRUCTURES, MATERIALS SCIENCE, ECONOMY OF CONSTRUCTION, INFORMATION MODELING / Collection "Sustainable development of the region: architecture, construction, transport". Materials of the 5th International Scientific and Practical Conference of the Institute of Architecture, Construction and Transport pp 2538 